УДК 591.156.1[597.95(591.8:591.477)]

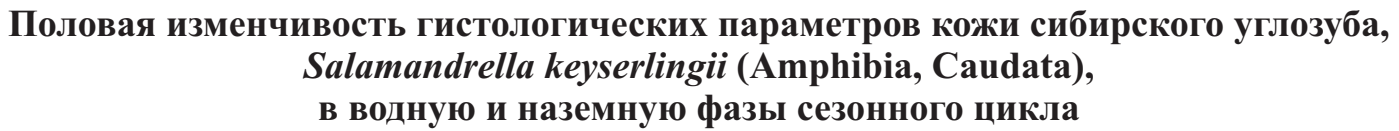

\author{
С. С. Евсеева ${ }^{1,2}$, В. В. Ярцев ${ }^{1-3 凶}$ \\ ${ }^{1}$ Национальный исследовательский Томский государственный университет \\ Россия, 634050, Томск, просп. Ленина, 36 \\ ${ }^{2}$ Сибирский федеральный научно-клинический цуентр \\ Федерального медико-биологического агентства \\ Россия, 636035, Томская область, Северск, Мира, 4 \\ ${ }^{3}$ Сибирский государственный медицинский университет \\ Россия, 634050, Томск, Московский тракт, 2 \\ E-mail:vadim_yartsev@mail.ru
}

Поступила в редакцию 15.07.2020, после доработки 10.08.2020, принята 17.08.2020

\begin{abstract}
Аннотация. Изучены гистологические особенности кожи спины (КС), горлового мешка (КГМ) и хвоста (КХ) половозрелых самцов и самок сибирского углозуба (Salamandrella keyserlingii) водного и наземного морфотипов. С помощью гистологических и статистических методик оценены половые различия по относительной площади эпидермиса, соединительной ткани дермы, её компактного и рыхлого слоёв, гранулярных и слизистых желёз. В водную фазу самцы по сравнению с самками характеризуются большей площадью элементов соединительной ткани дермы КГМ и КС, эпидермиса КХ, меньшими объёмами гранулярных желёз на верхнем участке КХ и элементов соединительной ткани дермы на нижнем участке КХ. В наземный период половые различия выражены слабо: самки по сравнению с самцами обладают бо́льшими объёмами соединительной ткани дермы и рыхлого её слоя на верхнем участке КХ. Среди структурных элементов кожи наибольший вклад в формирование половых различий вносят элементы соединительной ткани дермы.

Ключевые слова: хвостатые земноводные, покровы, морфотип, гистология кожи, вторичные половые признаки.
\end{abstract}

DOI: https://doi.org/10.18500/1814-6090-2020-20-3-4-100-106

\section{ВВЕДЕНИЕ}

Большинство земноводных умеренных широт обладают двухфазным годовым циклом, при котором взрослые особи только размножаются в водоёме, а большую часть года проводят на суше (Vitt, Caldwell, 2014). Для таких видов характерно формирование водного и наземного морфотипов, различных у самцов и самок.

Одним из факторов, формирующих половые различия по внешним морфологическим признакам у земноводных, являются гистологические процессы в коже, что показано на примере чёрного (Hynobius nigrescens Stejneger, 1907) и хоккайдского (Hynobius retardatus Dunn, 1923) углозубов (Aoto, 1950; Hasumi, Iwasawa, 1990). У самцов этих видов в отличие от самок в водную фазу годового цикла наблюдается увеличение объёма кожи шейной, туловищной и хвостовой частей тела, в то время как в наземный период самцы и самки морфологически схожи. Возникновение таких половых различий связано со значительным, по сравнению с самками, увеличением объёма соединительной ткани у самцов в водную фазу и её последующим уменьшением в наземную фазу годового цикла.

Сибирский углозуб, Salamandrella keyserlingii Dybowski, 1870, как и все земноводные с двухфазным годовым циклом, обладает выраженной сезонной изменчивостью, имеющей различные морфологические проявления у самцов и самок (Куранова, Ярцев, 2011; Ярцев, Евсеева, 2018 a, б). Особи водного и наземного морфотипов различаются по длине и ширине хвоста, ширине головы и клоаки, длине конечностей, гленоацетабулярному расстоянию (Куранова, Ярцев, 2011). Однако выявлено, что кожные структуры хвоста, горлового мешка и спины самцов и самок сибирского углозуба имеют схожую сезонную изменчивость (Ярцев, Евсеева, 2018 а, б).

Цель данной статьи - выявить половые различия гистологических параметров кожи особей S. keyserlingii водного и наземного морфотипов.

\section{МАТЕРИАЛ И МЕТОДЫ}

Исследованы половозрелые самцы $(n=10)$ и самки $(n=10)$ сибирского углозуба из научной кол- 
лекции кафедры зоологии позвоночных и экологии Национального исследовательского Томского государственного университета. Особи водной фазы отловлены в окрестностях г. Томска в конце апреля и начале мая 2012, 2014 гг., особи наземной фазы - в окрестностях с. Карагай в августе 2005 г. (юго-восток Западной Сибири, Томская область) и зафиксированы в 10\%-ном кислом формалине (детали см.: Ярцев, Евсеева, $2018 a, б)$.

У исследуемых экземпляров отобраны участки кожи с середины правой стороны хвоста, середины спины и горлового мешка по схеме, описанной ранее (Ярцев, Евсеева, 2018 a). Гистологическая обработка проведена классическими методами (Ярцев, 2019; Exbrayat, 2013). Материал обезвожен в растворах этанола возрастающей крепости, просветлён в бутаноле и заключён в парафин. Срезы толщиной 10 мкм изготовлены на ротационном микротоме RMD-3000 (MTPoint, Pocсия), окрашены пикрофуксином по Ван-Гизону и модифицированным азаном. Обзорная микроскопия препаратов, изготовление микрофотоснимков и измерения осуществлены с помощью микроскопа Axio Lab A1, камеры AxioCam ERc 5s и программного обеспечения ZEN 2012 (Carl Zeiss Microscopy, Германия).

При обзорной микроскопии структурные элементы кожи земноводных выделены по общепринятой схеме (Соколов, 1964; Fox, 1986; Hasumi, Iwasawa, 1992; Wells, 2007). По микрофотоснимкам измерены следующие показатели (мкм²): площадь эпидермиса (ПЭ), компактного слоя дермы (ПКС), гранулярных (ПГЖ) и слизистых (ПСЖ) желёз, пустот (ПП) и общая площадь исследуемой области (ИО). На основе измерений рассчитаны (мкм²): площадь исследуемого участка (ПИУ = ИО-ПП), дермы (ПД = ПИУ-ПЭ), соединительной ткани (ПСТ = ПД-ПГЖ-ПСЖ), рыхлой соединительной ткани (ПРСТ = ПСТПКС). Все абсолютные значения показателей переведены в относительные от ПИУ.

Статистическая обработка проведена с помощью программы Statistica 7.0 (StatSoft, США). Характер распределения вариационных рядов оценён с помощью критерия Шапиро - Уилка. Рассчитаны следующие описательные статистики: среднее арифметическое $(\bar{x})$, минимум ( $\mathrm{min})$ и максимум (max), стандартное отклонение $(\sigma)$, стандартная ошибка среднего $\left(m_{\bar{x}}\right)$, коэффициент вариации $(C v)$, уровень значимости $(P)$. В зависимости от результатов теста на характер распределения использован критерий Стьюдента $\left(t_{s t}\right)$ или Манна - Уитни (U-test). Результаты тестов принимались достоверными при достижении порога вероятности $5 \%(P \leq 0.05)$.

\section{РЕЗУЛЬТАТЫ}

Водная фаза. Сравнение гистологических параметров кожи верхнего участка хвоста самцов и самок водного морфотипа показало значимые статистические различия по ПЭ $\left(t_{s t}=-3.92 ; P<\right.$ $<0.05)$ и ПГЖ $\left(t_{s t}=2.88 ; P<0.05\right)$. На нижнем участке хвоста различия обнаружены по ПЭ $\left(t_{s t}=\right.$ $=-2.57 ; P<0.05)$, ПКС $\left(t_{s t}=2.43 ; P<0.05\right)$, ПСТ $\left(t_{s t}=\right.$ $=2.59 ; P<0.05)$ и ПРСТ $\left(t_{s t}=2.38 ; P<0.05\right)$. Участки кожи горлового мешка особей водного морфотипа отличаются по ПКС $\left(t_{s t}=-4.53 ; P<0.05\right)$ и ПСТ $\left(t_{s t}=-2.44 ; P<0.05\right)$. В коже спины значимые статистические различия обнаружены только по одному параметру - ПКС $\left(t_{s t}=-2.46 ; P<0.05\right)$ (рис. 1).

Самцы водного морфотипа по сравнению с самками характеризуются большей площадью эпидермиса хвоста, компактного слоя дермы спины, соединительной ткани и компактного слоя дермы горлового мешка, но меньшей площадью гранулярных желёз в верхней части хвоста, элементов соединительной ткани дермы нижнего участка хвоста (см. рис. 1).

Наземная фаза. В наземную фазу сезонного цикла половые различия выявлены только по ПСТ $\left(t_{s t}=2.51 ; P<0.05\right)$ и ПРСТ ( $U$-test: $Z=2.42$; $P \leq 0.05)$ в коже верхнего участка хвоста (рис. 2 ).

Самки наземного морфотипа, по сравнению с самцами, обладают большей площадью соединительной ткани дермы и её рыхлого слоя в коже верхнего участка хвоста (см. рис. 2).

\section{ОБСУЖДЕНИЕ}

Ввиду того, что размножение сибирского углозуба происходит в водную фазу сенного цикла, в это период, вероятно, должны формироваться изменения, связанные с адаптацией к водной среде, и наиболее проявляться возможные половые различия. При вхождении в водоём явно выраженные изменения в коже связаны с соединительной тканью: её объём увеличивается у представителей обоих полов в коже хвоста, а у самцов - ещё и в коже горлового мешка (Ярцев, Евсеева, $2018 a, б)$. Кроме этого, как у самцов, так и у самок, в коже хвоста увеличивается мощность эпидермиса, а общих изменений в коже спины не выявлено. Несмотря на значительную общность изменений у самцов и самок, степень их выраженности связана с полом, что приводит к формированию половых различий в данный период. Самцы имеют бо́льшую мощность эпидермиса хвоста, а самки - бо́льший объём соединительной ткани и размеры гранулярных желёз. Объём соединительной ткани в коже спины и горлового мешка у сам- 

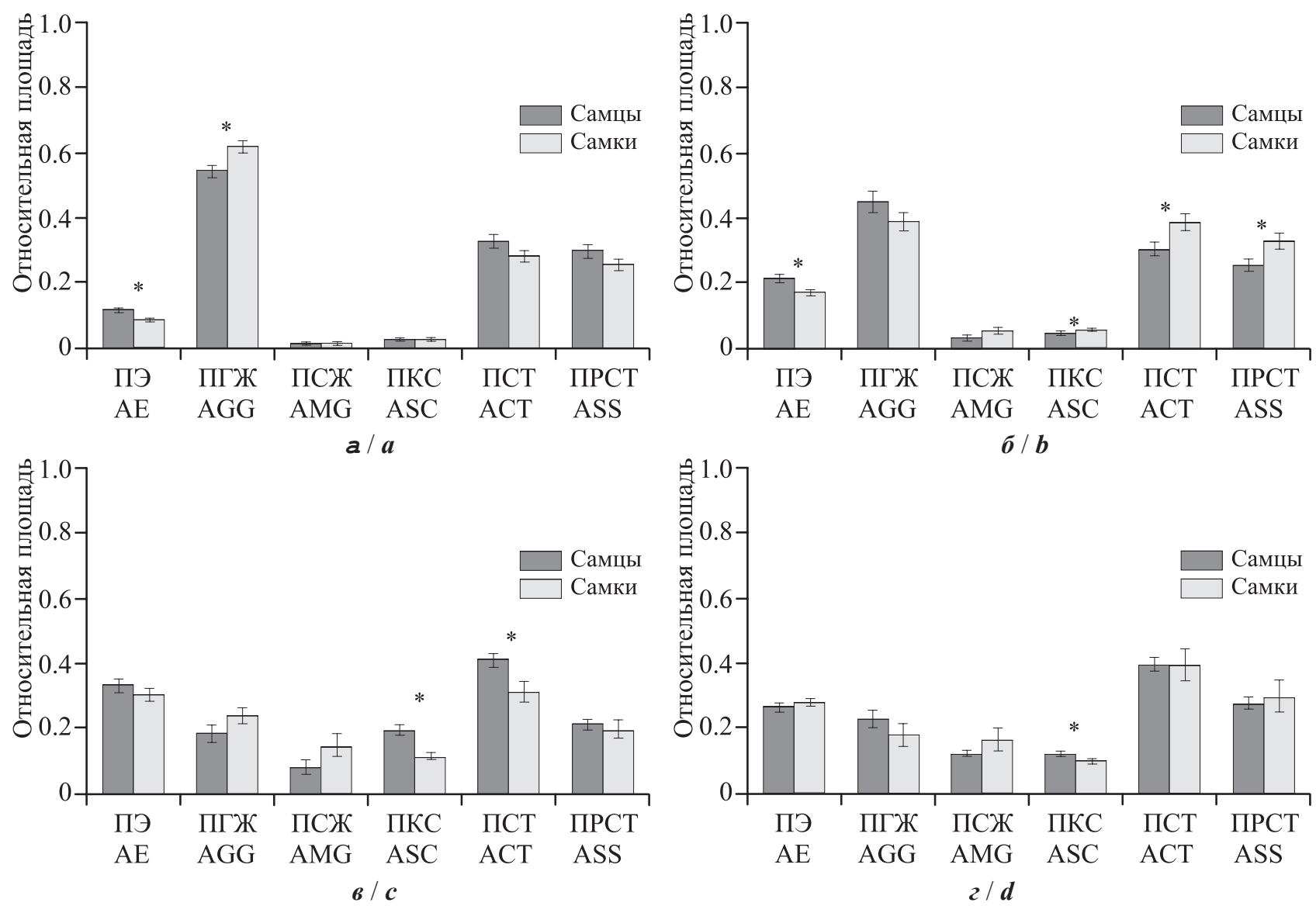

Рис. 1. Половая изменчивость гистологических параметров различных участков кожи Salamandrella keyserlingii в водную фазу сезонного цикла: $a$ - верхний участок хвоста, 6 - нижний участок хвоста, 8 - горловой мешок, 2 - спина. ПЭ - площадь эпидермиса, ПГЖ - площадь гранулярных желёз, ПСЖ - площадь слизистых желёз, ПКС - площадь компактного слоя, ПСТ - площадь соединительной ткани, ПРСТ - площадь рыхлой соединительной ткани. Астериск обозначает статистически значимые различия $(P \leq 0.05)$, планки погрешностей показывают $m_{\bar{x}}$

Fig. 1. Sexual variability of histological parameters of different skin regions of Salamandrella keyserlingii in the aquatic phase of its seasonal cycle: $a$ - upper part of caudal region, $b$ - lower part of caudal region, $c$ - throat region, $d$-dorsal region; $\mathrm{AE}$ - the area of epidermis, AGG - the area of granular glands, AMG - the area of mucous glands, ASC - the area of stratum compactum, ACT - the area of connective tissue, ASS - the area of stratum spongiosum. An asterisk denotes significant differences $(P \leq 0.05)$, vertical bars represent $\pm S E$ of the mean

цов в водную фазу больше, чем у самок. Всё это сказывается на внешнем облике животных в водную фазу: кожа самцов в целом выглядит более «отёчной», а хвост имеет большую высоту и уплощён в поперечном сечении в сравнении с самками, у которых он ниже, но визуально более толстый.

После выхода животных из водоёма - в наземную фазу - у самцов и самок в коже хвоста происходят уменьшение площади соединительной ткани и гипертрофия гранулярных желёз, а также увеличивается мощность эпидермиса горлового мешка (Ярцев, Евсеева, $2018 a$, б). При этом значительная часть половых различий по параметрам кожи исчезает, они сохраняются лишь в объёмах соединительной ткани кожи верхнего участка хвоста.

Полученные результаты согласуются с данными по половой изменчивости внешних морфо- логических признаков особей томской популяции данного вида: самцы в водный период обладают бо́льшими длиной и высотой хвоста и шириной головы по сравнению с самками, а в наземный меньшей длиной головы и относительной длиной хвоста (Куранова, Ярцев, 2011).

Вероятно, наблюдаемые половые различия гистологических параметров кожи связаны с действием половых гормонов и пролактина, концентрация которых у земноводных также изменяется в течение сезона активности (Hasumi et al., 1993; Mosconi et al., 1994). Показано, что действие данных гормонов сопряжено между собой: наибольшее влияние пролактина на морфологические признаки земноводных проявляется при повышении концентрации андрогенов в крови, а присутствие эстрогенов, напротив, может ингибировать 

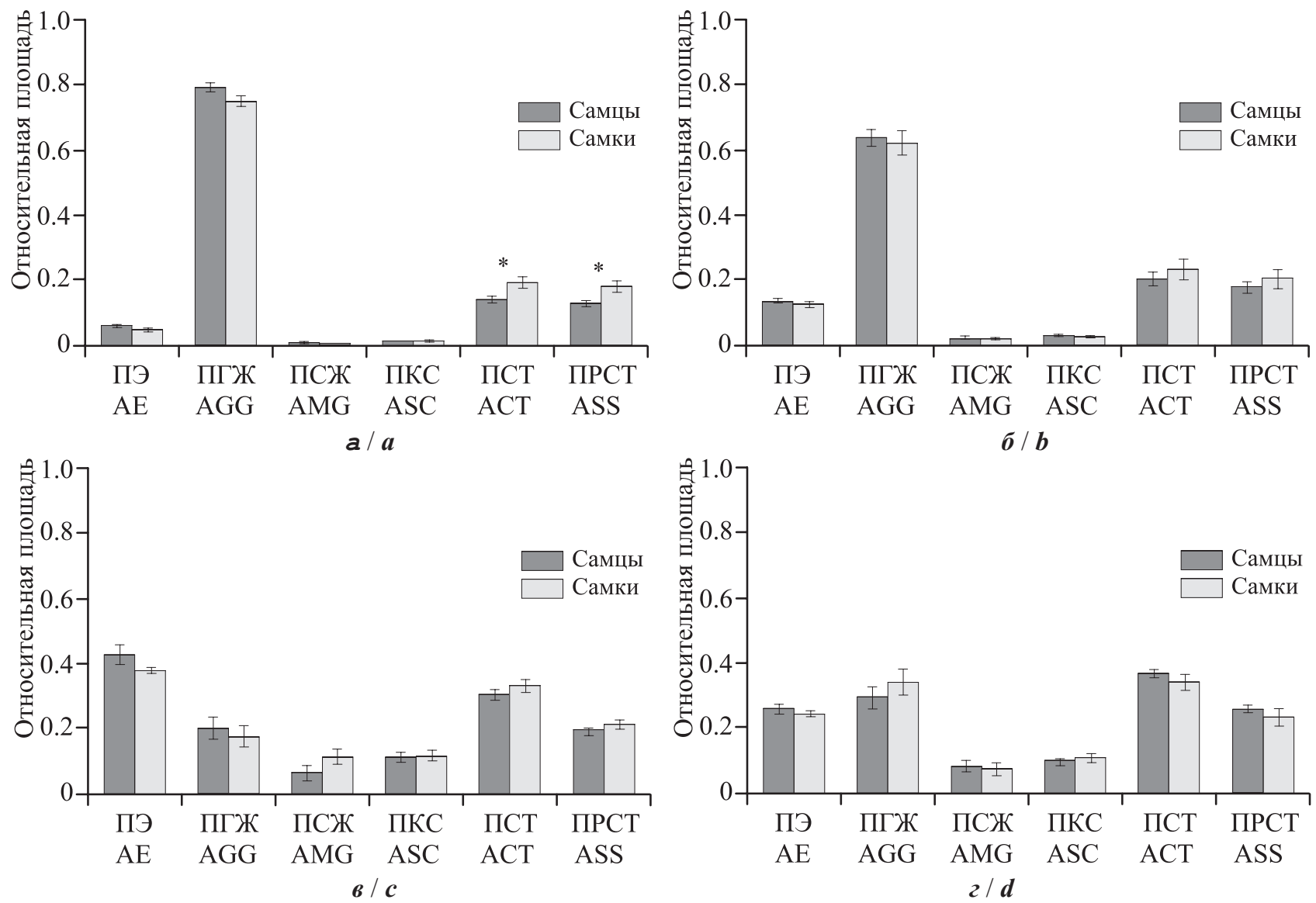

Рис. 2. Половая изменчивость гистологических параметров различных участков кожи Salamandrella keyserlingii в наземную фазу сезонного цикла: $а$ - верхний участок хвоста, $\sigma$ - нижний участок хвоста, 6 - горловой мешок, $2-$ спина. Условные обозначения см. рис. 1

Fig. 2. Sexual variability of histological parameters of different skin regions of Salamandrella keyserlingii in the terrestrial phase of its seasonal cycle: $a$ - upper part of caudal region, $b$ - lower part of caudal region, $c$ - throat region, $d$-dorsal region. The designations are as in Fig. 1

эффекты пролактина (Polzonetti-Magni et al., 1995; Norris, Lopez, 2011). Поскольку концентрация половых гормонов и пролактина изменяется сезонно, то и степень выраженности эффектов данных гормонов на морфологические признаки, в том числе и на тканевом уровне, изменяется в течение годового цикла. Так, у самцов Triturus carnifex (Mosconi et al., 1994) выявлено синхронное повышение концентрации пролактина и андрогенов в плазме крови в зимние месяцы с достижением пика в феврале - к периоду размножения данного вида. У самок, напротив, наибольший уровень пролактина в плазме крови отмечен в декабре, незадолго до увеличения концентрации вителлогенина, с последующим понижением и повторными меньшими пиками в мае.

Для самцов $H$. nigrescens обнаружено, что высокая концентрация андрогенов перед началом размножения запускает формирование водного морфотипа (Hasumi et al., 1993). При завершении данного процесса - уже у размножающихся сам- цов - уровень андрогенов снижается. У самок изменения такого рода не происходят, что связано с низким уровнем андрогенов в крови.

Если предположить наличие аналогичных тенденций сезонной динамики гормонов у сибирского углозуба, то, вероятно, подобные механизмы лежат в основе формирования разной степени выраженности половых различий у сибирского углозуба. Мужской водный морфотип формируется при совместном действии пролактина и андрогенов, но при низком уровне эстрогенов в начале периода размножения. Влияние этих гормонов приводит к большему, чем у самок, увеличению площади эпидермиса хвоста и элементов соединительной ткани дермы горлового мешка и спины. В этот же период у самок под действием пролактина и эстрогенов не происходит формирование столь явных признаков, характерных для самцов, но площадь элементов соединительной ткани дермы хвоста увеличивается, что приводит к формирова- 


\section{С. С. Евсеева, В. В. Ярцев}

нию округлого хвоста по женскому типу. В наземный период концентрация половых гормонов и пролактина снижается, в результате чего формируются схожие наземные морфотипы самцов и самок.

\section{ЗАКЛЮЧЕНИЕ}

Половая изменчивость гистологических параметров кожи в большей степени проявляется в водную фазу годового цикла по параметрам кожи хвоста. В наземный период половые различия выражены слабо. Среди структурных элементов кожи наибольший вклад в формирование половых различий вносят элементы соединительной ткани дермы.

\section{Благодарности}

Авторы выражают искреннюю благодарность В. Н. Курановой за предоставление возможности работы с авторским коллекционным материалом, а также ценные замечания и советы в процессе подготовки рукописи.

Работа выполнена при финансовой поддержке Российского фонда фундаментальных исследований (проект № 16-34-01055).

\section{СПИСОК ЛИТЕРАТУРЫ}

Куранова В. Н., Яриеев В. В. 2011. Половая и хронографическая изменчивость морфологических признаков сибирского углозуба, Salamandrella keyserlingii Dybowski, 1870 (юго-восток Западной Сибири) // Вопросы герпетологии : материалы Четвёртого съезда Герпетол. о-ва им. А. М. Никольского. СПб. : Русская коллекция. С. $136-141$.

Соколов В. Е. 1964. Морфологические приспособления кожного покрова земноводных фауны СССР к наземному образу жизни // Зоол. журн. Т. 18, вып. 9. С. 1410 - 1411.

Яриев В. В. 2019. Основы гистологической техники для зоологов : учеб.-метод. пособие для биологических специальностей вузов. Томск : Изд. Дом Том. гос. ун-та. $84 \mathrm{c}$.

Яриев В. В., Евсеева С. С. 2018 а. Гистологическая характеристика кожи самцов сибирского углозуба, Salamandrella keyserlingii (Caudata, Hynobiidae) в водную и наземную фазы сезонного цикла // Совре- менная герпетология. Т. 18, вып. 1/2. C. 54 - 63. DOI: https://doi.org/10.18500/1814-6090-2018-18-1-2-54-63

Яриев В. В., Евсеева С. С. 2018 б. Гистологическая характеристика кожи самок сибирского углозуба, Salamandrella keyserlingii (Caudata, Hynobiidae) в водную и наземную фазы сезонного цикла // Современная герпетология. Т. 18, вып. 3/4. С. 159 - 167. DOI: https://doi.org/10.18500/1814-6090-2018-18-3-4-159-167

Aoto T. 1950. A Remarkable Swelling of male Skin of a Salamander (Hynobius retardatus Dunn) in the Breeding Season // J. of the Faculty of Science Hokkaido University, Zoology. Vol. 10, № 1. P. 45 - 53.

Exbrayat J. M. 2013. Classical Methods of Visualization // Histochemical and Cytochemical Methods of Visualization / ed. J. M. Exbrayat. Boca Raton, London; New York : CRC Press Taylor and Francis Group. P. 3 - 58.

Fox H. 1986. Epidermis // Biology of the Integument. 2. Vertebrates / eds. J. Bereiter-Hahn, A. G. Matoltsy, K. S. Richards. Berlin ; Heidelberg ; New York : Springer-Verlag. P. $78-110$.

Hasumi M., Iwasawa H. 1990. Seasonal Changes in Body Shape and Mass in the Salamander, Hynobius nigrescens // J. of Herpetology. Vol. 24, № 2. P. 113 - 118.

Hasumi M., Iwasawa H. 1992. Wandering Behavior and Cutaneous Changes in Winter-dormant Male Salamanders (Hynobius nigrescens) // Herpetologica. Vol. 48, № 3. P. 279 - 287.

Hasumi M., Iwasawa H., Nagahama Y. 1993. Seasonal Changes in Plasma Concentrations of Sex Steroids in the Salamander Hynobius nigrescens // General and Comparative Endocrinology. Vol. 90, № 1. P. 51 - 57.

Mosconi G., Yamamoto K., Kikuyama S., Carnevali O., Mancuso A., Vellano C. 1994. Seasonal Changes of Plasma Prolactin Concentration in the Reproduction of the Crested Newt (Triturus carnifex Laur.) // General and Comparative Endocrinology. Vol. 95, № 3. P. 342 - 349.

Norris O., Lopez K. H. 2011. Hormones and Reproduction of Vertebrates. Vol. 2. Amphibian. San Diego : Academic Press. 240 p.

Polzonetti-Magni A., Carnevali O., Yamamoto K., Kikuyama S. 1995. Growth Hormone and Prolactin in Amphibian Reproduction // Zoological Science. Vol. 12, № 6. P. $683-694$.

Vitt L. J., Caldwell J. P. 2014. Herpetology : An Introductory Biology of Amphibians and Reptiles. 4th ed. Amsterdam : Academic Press. 757 p.

Wells K. D. 2007. The Ecology and Behavior of Amphibians. London : University of Chicago Press. 1148 p.

\section{Образец для цитирования:}

Евсеева C. С., Яриеев В. В. 2020. Половая изменчивость гистологических параметров кожи сибирского углозуба, Salamandrella keyserlingii (Amphibia, Caudata), в водную и наземную фазы сезонного цикла // Современная герпетология. Т. 20, вып. 3/4. С. 100 - 106. DOI: https://doi.org/10.18500/1814-6090-2020-20-3-4-100-106 
Половая изменчивость гистологических параметров кожи сибирского углозуба

\title{
Sexual Variability of Histological Skin Parameters of Salamandrella keyserlingii (Amphibia, Caudata) in the Aquatic and Terrestrial Phases of its Seasonal Cycle
}

\author{
Sophiya S. Evseeva ${ }^{1,2}$, https://orcid.org/0000-0002-7644-8501; vadim_yartsev@mail.ru \\ Vadim V. Yartsev 1-3凶, https://orcid.org/0000-0001-7789-7424; vadim_yartsev@mail.ru \\ ${ }^{1}$ National Research Tomsk State University \\ 36 Lenin Prosp., Tomsk 634050, Russia \\ ${ }^{2}$ Siberian Federal Scientific Clinical Center of Federal Medicobiological Agency \\ 4 Mira St., Seversk, Tomsk Region 636035, Russia \\ ${ }^{3}$ Siberian State Medical University \\ 2 Moskovski Trakt, Tomsk 634050, Russia
}

Received 15 July 2020, revised 10 August 2020, accepted 17 August 2020

\begin{abstract}
Histological features of the dorsal (DS), throat (TS) and tail skins (caudal skin, CS) were examined in Salamandrella keyserlingii females of the aquatic and terrestrial morphotypes. Using histological and statistical methods, sexual differences in the relative areas of epidermis, strata compactum and spongiosum, connective tissue in the whole, granular and mucous glands were measured. In the aquatic phase, males, in comparison with females, have larger areas of the connective tissue in TS and DS, a larger area of the epidermis in CS, but smaller areas of the granular glands in the upper part of CS and elements of the connective tissue in the lower part of CS. In the terrestrial phase, sexual differences were weakly expressed. Females, in comparison with males, have larger areas of the connective tissue in the whole and its stratum spongiosum in the upper part of CS. Elements of the connective tissue made the greatest contribution to the formation of sexual differences of the skin in S. keyselingii.
\end{abstract}

Keywords: tailed amphibians, integument, morphotype, skin histology, secondary sexual characteristics.

DOI: https://doi.org/10.18500/1814-6090-2020-20-3-4-100-106

This article is an open access article distributed under the terms and conditions of the Creative Commons Attribution 4.0 License

Acknowledgements: This study was supported by the Russian Foundation for Basic Research (project No. 1634-01055).

\section{REFERENCES}

Kuranova V. N., Yartsev V. V. Sexual, Seasonal, and Interannual Variability of Morphological Characteristics of Siberian Newt, Salamandrella keyserlingii Dybowski, 1870, from the South-east of Western Siberia. The Problems of Herpetology: Proceedings of the 4th Meeting of the Nikolsky Herpetological Society. Saint Petersburg, Russkaia kollektsiia Publ., 2011, pp. 136-141 (in Russian).

Sokolov V. E. Morphological Adaptations of the Amphibian Skin in USSR Fauna to the Terrestrial Mode of Life. Zoologicheskii Zhurnal, 1964, vol. 18, iss. 9, pp. 1410-1411 (in Russian).

Yartsev V. V. Osnovy gistologicheskoy tekhniki dlya zoologov: uchebno-metodicheskoye posobiye dlya biologicheskikh spetsialnostey vuzov [Basics of Histological Techniques for Zoologists: Teaching Aid for Biological Specialties of Universities]. Tomsk, Izdatel'skii Dom Tomskogo gosudarstvennogo universiteta, 2019. 84 p. (in Russian).
Yartsev V. V., Evseeva S. S. Histological Characteristics of the Skin of Salamandrella keyserlingii (Caudata, Hynobiidae) Males in the Aquatic and Terrestrial Phases of Their Seasonal Cycle. Current Studies in Herpetology, $2018 a$, vol. 18, iss. 1-2, pp. 54-63 (in Russian). DOI: https://doi.org/10.18500/1814-6090-2018-18-1-2-54-63

Yartsev V. V., Evseeva S. S. Histological Characteristics of the Skin of Salamandrella keyserlingii (Caudata, Hynobiidae) Females in Aqutic and Terrestrial Phases of Seasonal Cycle. Current Studies in Herpetology, 2018 b, vol. 18, iss. 3-4, pp. 159-167 (in Russian). DOI: https://doi.org/10.18500/1814-6090-2018-18-3-4159-167

Aoto T. A Remarkable Swelling of male Skin of a Salamander (Hynobius retardatus Dunn) in the Breeding Season. J. of the Faculty of Science Hokkaido University, Zoology, 1950, vol. 10, no. 1, pp. 45-53.

Exbrayat J. M. Classical Methods of Visualization. In: J. M. Exbrayat, ed. Histochemical and Cytochemical Methods of Visualization. Boca Raton, London, 
New York, CRC Press Taylor and Francis Group, 2013, pp. 3-58.

Fox H. Epidermis. In: J. Bereiter-Hahn, A. G. Matoltsy, K. S. Richards, eds. Biology of the Integument. 2 Vertebrates. Berlin, Heidelberg, New York, Springer-Verlag, 1986. pp. 78-110.

Hasumi M., Iwasawa H. Seasonal Changes in Body Shape and Mass in the Salamander, Hynobius nigrescens. J. of Herpetology, 1990, vol. 24, no. 2, pp. 113-118.

Hasumi M., Iwasawa H. Wandering Behavior and Cutaneous Changes in Winter-dormant Male Salamanders (Hynobius nigrescens). Herpetologica, 1992, vol. 48, no. 3, pp. 279-287.

Hasumi M., Iwasawa H., Nagahama Y. Seasonal Changes in Plasma Concentrations of Sex Steroids in the Salamander Hynobius nigrescens. General and Comparative Endocrinology, 1993, vol. 90, no. 1, pp. 51-57.
Mosconi G., Yamamoto K., Kikuyama S., Carnevali O., Mancuso A., Vellano C. Seasonal Changes of Plasma Prolactin Concentration in the Reproduction of the Crested Newt (Triturus carnifex Laur.). General and Comparative Endocrinology, 1994, vol. 95, no. 3, pp. 342-349.

Norris O., Lopez K. H. Hormones and Reproduction of Vertebrates. Vol. 2. Amphibian. San Diego, Academic Press, 2011. 240 p.

Polzonetti-Magni A., Carnevali O., Yamamoto K., Kikuyama S. Growth Hormone and Prolactin in Amphibian Reproduction. Zoological Science, 1995, vol. 12, no. 6, pp. 683-694.

Vitt L. J., Caldwell J. P. Herpetology: An Introductory Biology of Amphibians and Reptiles. 4th ed. Amsterdam, Academic Press, 2014. 757 p.

Wells K. D. The Ecology and Behavior of Amphibians. London, University of Chicago Press, 2007. 1148 p.

\section{Cite this article as:}

Evseeva S. S., Yartsev V. V. Sexual Variability of Histological Skin Parameters of Salamandrella keyserlingii (Amphibia, Caudata) in the Aquatic and Terrestrial Phases of its Seasonal Cycle. Current Studies in Herpetology, 2020, vol. 20, iss. 3-4, pp. 100-106 (in Russian). DOI: https://doi.org/10.18500/1814-6090-2020-20-3-4-100-106 